\title{
Experiences of Academic Librarians Serving as Interim Library Leaders
}

\section{Kathy M. Irwin and Susann deVries}

\begin{abstract}
Using a mixed-methods approach, the researchers explored the experiences of 108 academic librarians who served as interim library leaders at U.S. institutions of higher education between 2012 and 2017. Statistical analysis showed no associations between gender, type of institution, or degree-granting level with the duration of interim service or whether a respondent applied for or was hired as the permanent leader. The authors provide recommendations for future interim library leaders and the university executives who appoint them. Serving as an interim library leader can be a once-in-a lifetime opportunity well worth the experience.
\end{abstract}

\section{Introduction}

Library leadership is a recurrent topic of research articles. Despite the regular appointment of interim leaders in academic libraries, researchers have not studied this niche area of leadership in depth. A search for "leadership" in the Library Literature E Information Science Full Text database resulted in 270 articles published in 2017. Adding the keyword "interim" returned nine articles, but eight were not about interim leadership. Instead, these articles appeared because the author's job title included the word "interim." Similarly, a search of articles published between 2007 and 2017 resulted in 2,769 articles about leadership and only 4 articles about interim leadership. This gap in literature poses a problem for librarians seeking information and advice about interim leadership.

Unlike the hiring process for a permanent leader, librarians asked to serve as interim leaders may have little notice and must make a fast decision. When a leader retires, the incumbent may give ample notice; but, when a leader leaves a position for other reasons, little notice may be given. ${ }^{1}$ The search for the successor takes time, and the provost may appoint an interim leader to oversee operations until the institution can complete a search for the new permanent leader. ${ }^{2}$ An individual asked to serve as an interim leader quickly needs to assess the advantages and disadvantages of the interim role as well as understand the expectations and authority of the position.

A librarian appointed to an interim dean or interim university librarian position may have less experience and fewer skills compared to permanent leaders. According to Mundt and Fountaine, individuals appointed as interim deans typically are associate or assistant deans

\footnotetext{
${ }^{*}$ Kathy M. Irwin is Dean of Libraries at Central Michigan University; email: irwin1km@cmich.edu. Susann deVries is Dean of Libraries at Western Kentucky University; email: susann.devries@wku.edu. (C2019 Kathy M. Irwin and Susann deVries, Attribution-NonCommercial (http://creativecommons.org/licenses/by-nc/4.0/) CC BY-NC.
} 
or faculty members. ${ }^{3}$ Farrell speculated that interim leaders have less leadership training and preparation than permanent leaders. ${ }^{4}$ People develop leadership skills gradually and often move up in leadership rank sequentially. ${ }^{5}$ The interim leader who is a library department head or associate dean may be familiar with some library operations, personnel matters, and internal politics, but library faculty who serve as interim leaders may have little management experience. Additionally, interim library leaders may have limited knowledge of the operations and politics of the whole university. According to Fountaine, most interim leaders do not have experience as deans, yet they face new duties such as managing external relationships and directing the whole organization. ${ }^{6}$ While Medeiros acknowledged that his duties as the interim director were very different from his duties as associate director, he admitted that, at first, he did not expect that would be the case. ${ }^{7}$

Both authors of this study served as interim library leaders at public universities in Michigan, one for an eight-month period and the other for two years. The authors appreciated the support they provided each other during their interim appointments and were curious about other interim leaders' experiences. The library literature about interim leadership answered some questions but also raised more questions. Therefore, the authors undertook this research study to gain personal insights and to provide future interim leaders with advice based on the experiences of many.

The purpose of this study was to build knowledge about top-level interim library leadership by analyzing the experiences of librarians who served as interim library deans, interim university librarians, or interim library directors. The results of this research will provide future interim library leaders with information to help them be effective in this unique and temporary role. The results also will inform provosts and other university executives about the concerns and needs of interim library leaders. The authors posed four research questions: 1. What similarities exist among the experiences of librarians who have served as interim library leaders? 2. What differences exist among the experiences of librarians who have served as interim library leaders? 3 . What recommendations do interim library leaders offer to others who may be asked to serve in an interim role? 4 . What recommendations do interim library leaders offer to university executives who may appoint an interim library leader?

\section{Literature Review}

While the appointment of interim leaders is a frequent practice in higher education, librarians have published few articles about their experiences as interim leaders. Most of these articles are personal narratives, interviews, or editorials. Due to the low number of library-specific articles, this literature review also draws from articles about interim deans in academic colleges. Collectively, these authors addressed the benefits and challenges of interim appointments, the interim leader's role and charge, learning experiences and relationships during the interim period, and the transition period in the end. This review does not include an overview of library leadership literature because the quantity of articles is too large to review.

Individuals asked to serve as interim leaders need to consider the benefits and challenges of the interim role. According to Farrell and Medeiros, interim library leaders have a unique opportunity to try out a new career. ${ }^{8}$ Interim leaders often receive additional compensation, although Farrell and Stover observed that additional pay does not compensate for the challenges one may face such as length of work day, stress, and exhaustion. ${ }^{9}$ Some interim leaders negotiated benefits such as additional vacation time, increased professional development 
funding, increased research funding, or a sabbatical period following the appointment. ${ }^{10}$ While some institutions backfill the interim leader's regular position, assigning it to another person on a temporary basis, the interim leader might spend time performing duties of both positions. ${ }^{11}$ The interim leader often serves indefinitely until a new leader begins, although most interim assignments last one year. ${ }^{12}$ Bachrach, Farrell, and Mundt recommended requesting the details of the appointment in writing. ${ }^{13}$ To aid individuals in making a decision, Mundt's article provided questions to ask about one's career goals, potential candidacy, the expectations of the position, the level of support available, and the duration of the appointment. ${ }^{14}$

An interim leader needs clarity about the role. Boyle, Chestnut, Hogue, and Zgarrick and Farrell recommended that university leaders specify the expectations, scope, priorities, and authority of the interim position and communicate the same information to stakeholders. ${ }^{15}$ Some interim leaders made significant changes, while others maintained the status quo. Hall served as interim dean during a time of reorganization, budget cuts, layoffs, and curriculum reform. Likewise, Doksansky took an active role in union negotiations, reorganization, and facility changes while serving as interim director. ${ }^{16}$ However, Bachrach and Munde described their interim experiences as a time of "limbo."17 Despite their different experiences, both Doksansky and Munde described making necessary changes without implementing a new vision or inflexible agenda. ${ }^{18}$

Interim leaders may question whether to apply for the permanent position. Farrell and Munde noted that some institutions do not allow interim leaders to apply for the permanent position; thus, potential candidates need to ascertain their institutions' policies. ${ }^{19}$ Medeiros and Newcombe and Donovan recommended that the interim leader not apply for the permanent position because other people may question the interim leader's motives and decisions. ${ }^{20}$ Galbraith, Smith, and Walker studied succession planning practices in large research libraries and reported that more than half of the study's participants preferred to hire external candidates for the library's top-most leadership position. ${ }^{21}$ While their findings showed that hiring an internal candidate resulted in a smoother transition, respondents stated that external candidates were "more qualified" and brought "fresh perspectives or new ideas." ${ }^{22}$ The decision to apply for the permanent position while also serving as the interim leader requires thoughtful consideration and knowledge of oneself and the institution.

Interim leaders have an opportunity to learn new or enhance existing skills. They might develop or enhance skills in communication, interpersonal relationships, change management, budgeting, decision making, strategic planning, fundraising, being flexible and responsive, and articulating a vision. ${ }^{23}$ In addition to learning new skills, Farrell pointed out that interim leaders can showcase skills they possess but do not use in their regular position. ${ }^{24}$ While Munde believed others would consider her to be weak if she did not do everything herself, Doksansky stressed that the interim leader cannot be an expert in all operations..$^{25}$ Several authors observed that reporting to an administrator outside the library provided an opportunity to learn more about the institution and to educate that person about the library. ${ }^{26}$ Specifically, Munde enjoyed learning more about the business and social aspects of academic affairs. ${ }^{27}$ Deemer appreciated seeing the library from a different perspective and was better able to support the administration as a result of his interim leadership experience. ${ }^{28}$

Relationships with library employees may change during the interim period. Fountaine noted that employees might be hypercritical, might become friendlier, or might distance themselves from an existing relationship. ${ }^{29}$ Munde added that some employees might at- 
tempt to take advantage of the interim period for personal gain. ${ }^{30}$ Employees might gain or lose respect for the interim leader based on the impact of the leader's decisions. ${ }^{31}$ Klare encouraged interim leaders to consult with their mentors and carefully select confidants. ${ }^{32}$ Fountaine pointed out that the previous leader selected the current management team, and, because the team members will soon have another new boss, they might not warm to or accept the interim leader. ${ }^{33}$

While some interim responsibilities may become routine, interim leaders may experience unforeseen situations and feelings. Logan and Farrell reported that the volume and pace of work was greater than what one might expect. ${ }^{34}$ According to Hall, the dean's job has a higher degree of complexity and faster rate of change compared to that of an associate dean or a faculty member. ${ }^{35}$ Hall noticed that his interim position did not feel temporary and disclosed that his new identity as dean did not seem to be "the real me."36 Similarly, Klare described her sudden transition as one of "personal displacement" and advised leaders to take time to reflect and apply the principles of emotional intelligence. ${ }^{37}$ Munde recommended that interim leaders accept the fact that they will make mistakes and forgive themselves. ${ }^{38}$ During an interview with Shoaf, Doksansky recommended that interim leaders maintain a sense of humor and seek support from colleagues on campus, from librarians at other institutions, and from friends and family. ${ }^{39}$

At the conclusion of the interim period, both the institution and the interim leader will experience a transition. According to Boyle et al., university executives expect interim leaders to prepare for and assist the new leader during the transition, and Medeiros advised interim leaders be direct and honest with the new leader. ${ }^{40}$ Upon returning to one's former position, one might feel lost, bored, resentful, demoted, or less influential. ${ }^{41}$ Some individuals might find that their former position no longer exists or is unavailable. ${ }^{42}$ Boyle also observed that other institutions actively recruit interim leaders. ${ }^{43}$ Finally, Mundt encouraged individuals to take time to write down their accomplishments and begin planning their next career step. ${ }^{44}$ The transition period will culminate in a new normal for all parties.

\section{Methodology}

The researchers used a mixed-methods design that included two phases: a 27-question survey conducted in late 2016 followed by telephone interviews conducted in early 2017. From the survey, the researchers sought to document and analyze data about interim leadership in U.S. academic libraries between 2012 and 2017 and solicit volunteers for the interview phase. The authors developed survey and interview questions based on their own experiences and on issues raised in the literature review. The first author asked a college faculty member to review the questions, and both authors obtained an exemption from their respective institutional review boards.

The researchers set up the questionnaire in SurveyMonkey. In early December 2016, they emailed the survey link to colleagues and posted a call for survey participants to several discussion lists. To reach a large number of academic librarians, the researchers posted to three discussion lists maintained by the Association of College and Research Libraries (ACRL): University Libraries, College Libraries, and Community \& Junior College Libraries. To reach library administrators, the authors posted to three discussion lists maintained by the Library Leadership \& Management Association (LLAMA): Library Administration Discussion List, Middle Managers Discussion List, and Women Administrators Discussion List. No official 
list of interim library leaders exists; thus, the authors used a convenience sample. In the survey, participants indicated the title of their interim position and whether they served in the top-most library leadership position. The survey's skip logic routed respondents to a "not eligible" webpage if they did not serve in the top leadership position. (See survey instrument in appendix A.) After closing the survey in early January 2017, the first author downloaded the results to Excel and coded the comments. For question 15, the only open-ended question, the first author coded each comment with topics that emerged from the text, then grouped similar topics into broader categories or themes. The authors worked with the Statistical Consulting Center at Central Michigan University to analyze the data using SPSS.

During the second phase of the research project, the researchers sought to verify survey findings and explore individual stories and reflections in depth. The authors selected 12 representative individuals who completed the survey and expressed interest in participating in an interview. The structured interview protocol consisted of twelve questions administered by telephone. (See interview questions in appendix B.) Between mid-January and the end of February 2017, each researcher conducted five interviews and typed the responses into a SurveyMonkey questionnaire during or after each interview. The researchers did not record the interviews. The second author printed out the transcripts and hand-coded the interview transcripts, assigning topics that emerged from the text and grouping similar topics into broader categories or themes. While three of the themes from the interviews overlapped with the survey themes, the interviews yielded one additional theme.

\section{Survey Results}

Of the 165 individuals who began the survey, 108 individuals completed all questions and 58 agreed to a follow-up interview. The majority of survey participants were females $(75.7 \%)$ who worked at public institutions (65.7\%) that confer master's degrees (50.0\%). According to the U.S. Census report, Full-Time, Year-Round Workers and Median Earnings 2015, 80.7 percent of librarians were women. ${ }^{45}$ The percentage of women who participated in the survey is consistent with national census data. The 2015 Carnegie Classifications Update listed more than twice as many master's degree-conferring institutions as doctorate-granting institutions. ${ }^{46}$ The survey responses were consistent with this statistic as well: nearly twice as many individuals from master's institutions (50.0\%) participated in the survey compared to individuals from doctoral institutions $(26.9 \%)$. However, the proportion of survey participants from baccalaureate colleges $(12.9 \%)$ and associate's colleges $(9.3 \%)$ was not consistent with national data. According to the Carnegie Classifications, private institutions of higher education outnumber public institutions nearly 2 to $1 .{ }^{47} \mathrm{But}$ the opposite was true in the survey responses: participants from public institutions (65.7\%) outnumbered respondents from private institutions (34.3\%) nearly 2 to 1 . (See table 1 for additional survey participant demographics and institutional characteristics.)

The Pearson's chi-square test of association between two categorical variables showed no associations between gender, type of institution, or degree-granting level with the duration of interim service or whether a respondent applied for or was hired as the permanent leader. The observed and expected frequencies were the same or very similar. Table 2 lists the Pearson chi-square, degrees of freedom, and asymptotic significance for each of these categorical variables. The participants' experiences with the duration of the interim period, whether they applied for the permanent position or whether they were hired for the permanent position, 


\begin{tabular}{|c|c|c|c|}
\hline \multicolumn{4}{|c|}{$\begin{array}{c}\text { TABLE } 1 \\
\text { Number of Respondents by Category: Survey } n=108 \text {, Interview } n=10\end{array}$} \\
\hline Category & Response & $\begin{array}{c}\text { \# Survey } \\
\text { Respondents }\end{array}$ & $\begin{array}{l}\text { \# Interview } \\
\text { Participants }\end{array}$ \\
\hline \multicolumn{4}{|l|}{ Gender } \\
\hline & Female & 83 & 8 \\
\hline & Male & 27 & 2 \\
\hline & Skipped question & 1 & 0 \\
\hline \multicolumn{4}{|c|}{ Type of institution } \\
\hline & Public & 71 & 8 \\
\hline & Private & 37 & 2 \\
\hline \multicolumn{4}{|c|}{ Carnegie Classification } \\
\hline & Doctoral institutions & 29 & 4 \\
\hline & Masters institutions & 54 & 5 \\
\hline & Baccalaureate colleges & 14 & 0 \\
\hline & Community colleges & 10 & 1 \\
\hline & Other & 1 & 0 \\
\hline \multicolumn{4}{|c|}{ Student headcount } \\
\hline & Fewer than 5,000 students & 52 & 1 \\
\hline & $5,001-10,000$ students & 19 & 5 \\
\hline & $10,001-20,000$ students & 19 & 1 \\
\hline & More than 20,000 students & 18 & 3 \\
\hline \multicolumn{4}{|c|}{ Number of library employees } \\
\hline & 1-25 employees & 67 & 1 \\
\hline & 26-50 employees & 20 & 4 \\
\hline & 51-100 employees & 12 & 0 \\
\hline & More than 100 employees & 9 & 3 \\
\hline \multicolumn{4}{|c|}{ Size of library budget } \\
\hline & Less than $\$ 1$ million & 35 & 2 \\
\hline & $\$ 1.0-4.9$ million & 43 & 3 \\
\hline & $\$ 5.0-9.9$ million & 17 & 2 \\
\hline & Over $\$ 10$ million & 11 & 3 \\
\hline & Skipped question & 2 & 0 \\
\hline \multicolumn{4}{|c|}{ Interim year } \\
\hline & 2012 & 19 & 2 \\
\hline & 2013 & 19 & 3 \\
\hline & 2014 & 23 & 3 \\
\hline & 2015 & 38 & 4 \\
\hline & 2016 & 47 & 3 \\
\hline & 2017 & 18 & 1 \\
\hline
\end{tabular}




\begin{tabular}{|c|c|c|c|}
\hline \multicolumn{4}{|l|}{$\begin{array}{c}\text { TABLE } 2 \\
\text { Pearson's Chi-Square Test of Association }\end{array}$} \\
\hline & Value & df & $\begin{array}{c}\text { Asymptotic } \\
\text { Significance } \\
\text { (2-sided) }\end{array}$ \\
\hline $\begin{array}{l}\text { Q7. How long did you serve or have you been serving in the interim } \\
\text { position? * Q17. To which gender do you most identify? }\end{array}$ & 2.469 & 6 & .872 \\
\hline $\begin{array}{l}\text { Q7. How long did you serve or have you been serving in the interim } \\
\text { position? * Q21. Type of institution (public or private). }\end{array}$ & 11.140 & 6 & .084 \\
\hline $\begin{array}{l}\text { Q7. How long did you serve or have you been serving in the interim position? } \\
{ }^{*} \text { Q22. Degrees conferred (doctoral, masters, baccalaureate, associates) }\end{array}$ & 31.549 & 24 & .139 \\
\hline $\begin{array}{l}\text { Q12. Did you apply for the permanent position? * Q17. To which gender do } \\
\text { you most identify? }\end{array}$ & .671 & 2 & .715 \\
\hline $\begin{array}{l}\text { Q12. Did you apply for the permanent position? * Q21. Type of institution } \\
\text { (public or private). }\end{array}$ & 2.792 & 2 & .248 \\
\hline $\begin{array}{l}\text { Q12. Did you apply for the permanent position?* Q22. Degrees conferred } \\
\text { (doctoral, masters, baccalaureate, associates) }\end{array}$ & 10.178 & 8 & .253 \\
\hline $\begin{array}{l}\text { Q13. Were you hired for the permanent position? * Q17. To which gender do } \\
\text { you most identify? }\end{array}$ & 2.543 & 3 & .468 \\
\hline $\begin{array}{l}\text { Q13. Were you hired for the permanent position? }{ }^{*} \text { Q21. Type of institution } \\
\text { (public or private). }\end{array}$ & 1.695 & 3 & .638 \\
\hline $\begin{array}{l}\text { Q13. Were you hired for the permanent position? * Q22. Degrees conferred } \\
\text { (doctoral, masters, baccalaureate, associates) }\end{array}$ & 9.937 & 12 & .621 \\
\hline
\end{tabular}

were not different based on gender, type of institution, or degree-granting level.

The reason for the interim period and the respondents' length of service varied. Nearly half $(48.2 \%)$ of respondents indicated that their appointment as an interim library leader was due to a retirement, while less than one third (27.8\%) of respondents indicated that the previous leader left for a job at another institution. Other reasons given for the vacancy included that the previous leader was removed or terminated, resigned, was on medical leave, died, was promoted to a position elsewhere in the same institution, or stepped down to a faculty position. As depicted in figure 1, participants' responses varied regarding years of service at the same institution (Q18), total years as a librarian (Q19), and total years as a library leader (Q20) before their appointment as an interim library leader. Interestingly, a greater percentage of respondents who were appointed to interim leadership roles either had worked at the institution for a shorter period or had fewer years of previous leadership experience.

In most cases, the interim period extended longer than expected. Figure 2 depicts the period respondents were asked to serve as the interim leader (Q6), the actual length of time they served (Q7), and what they viewed as the ideal length of service (Q9). In question 6, 41 respondents selected "other," and the top two reasons stated were "indefinite/no period specified" and "until the position was filled." Numerous survey respondents recommended that executive leaders set a fixed, brief term of service and begin a search for a permanent leader as soon as possible. Reasons for an extension included budget challenges, hiring freezes, the initial search failed, or other top-level positions were or became vacant (other Deans, the Provost, the President). When asked about the ideal period to serve as an interim leader, one individual replied, 'I don't know 


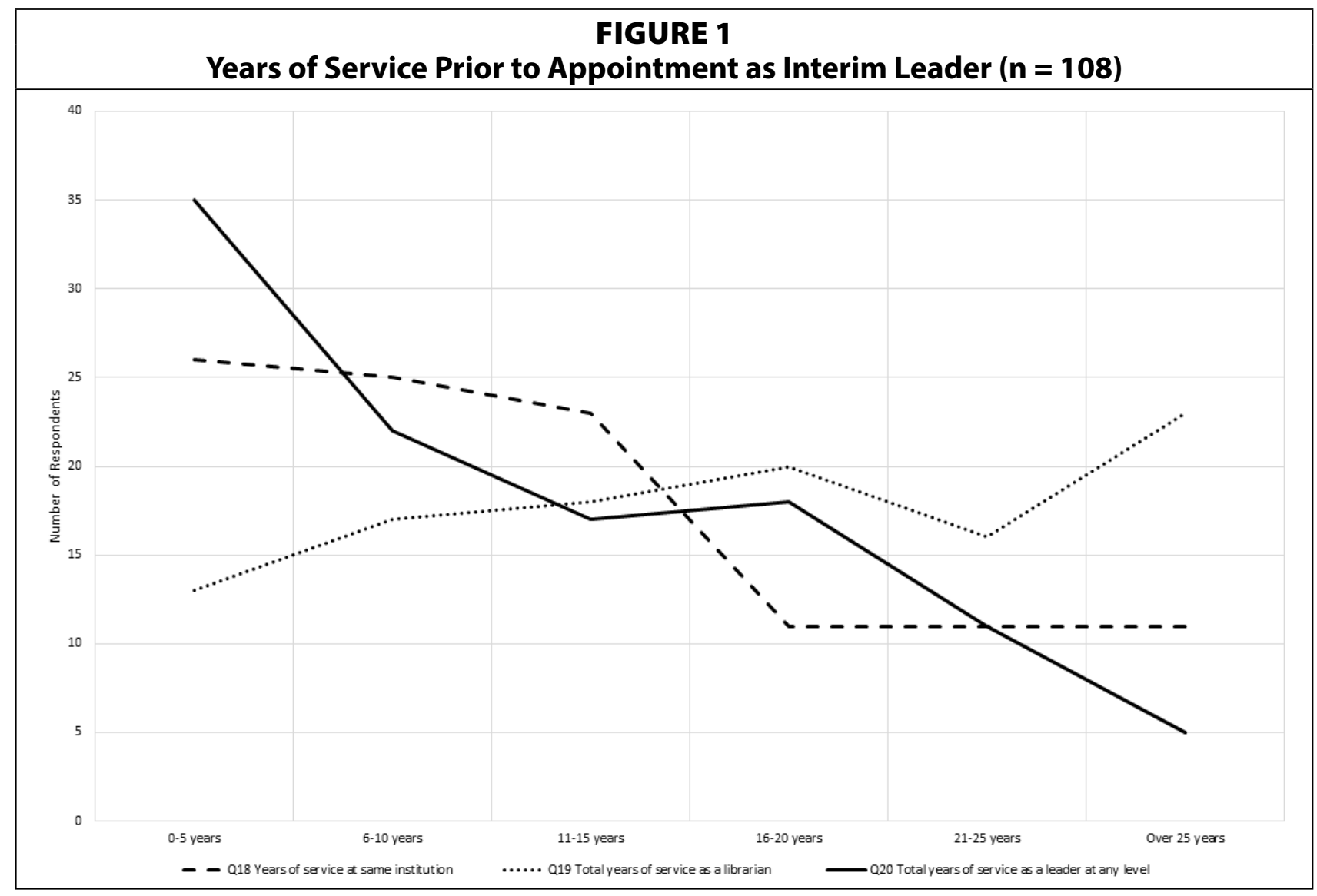

\section{FIGURE 2}

Duration of Interim Appointment $(n=108)$

60

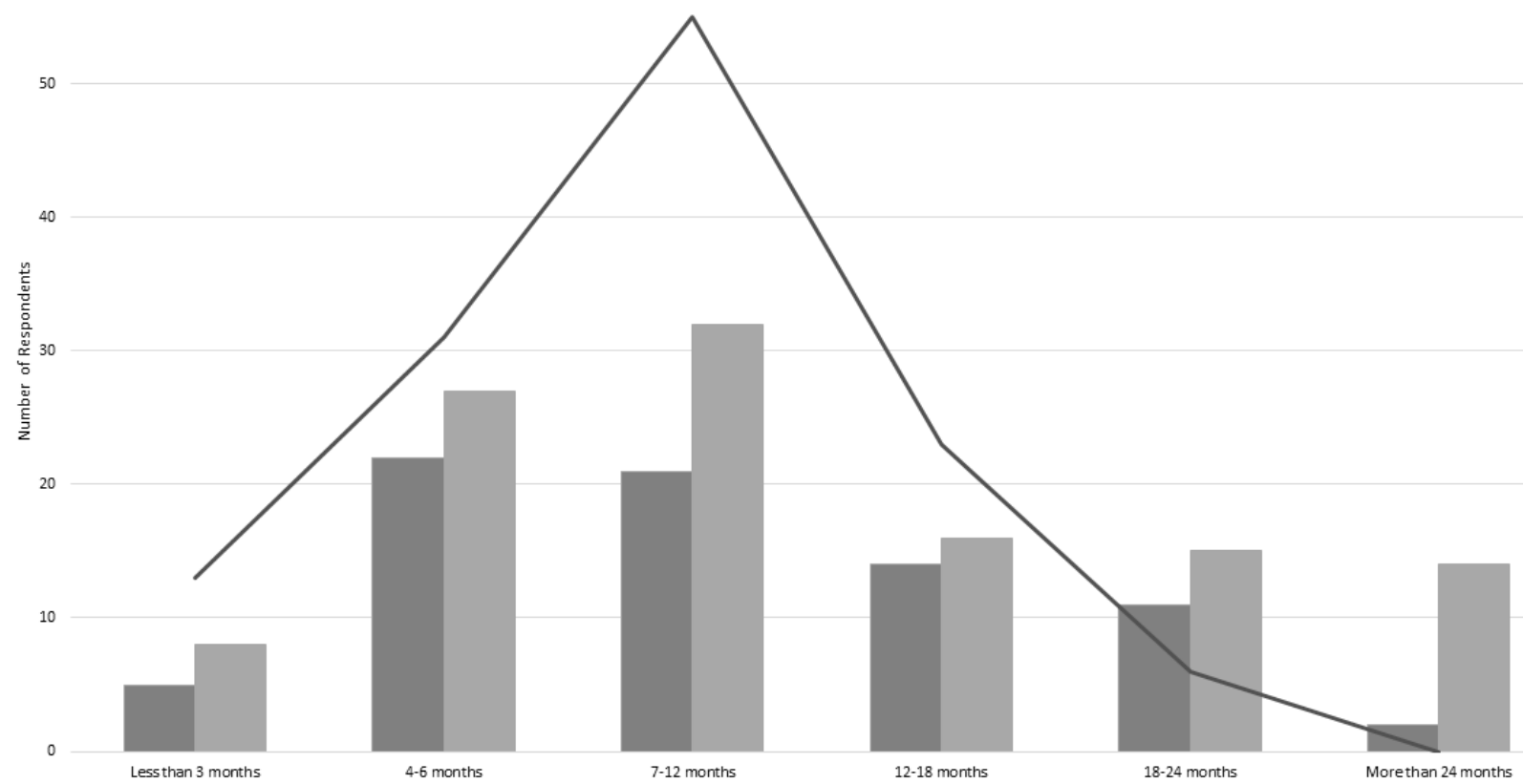


that there is an 'ideal' amount of time since every situation is different," and another person said there is "no universally applicable answer in my opinion." Several respondents stated that the interim period could be as short as 4 to 6 months if the incumbent's departure is planned and if the search is a priority, but it could take longer if the incumbent leaves unexpectedly.

Participants acknowledged it was challenging and stressful to serve as interim leader while continuing to perform their regular job. Three-quarters of respondents (75.9\%) held their regular position concurrently with the interim position, while a small percentage of respondents (13.9\%) reported that their regular position was backfilled temporarily. In many cases when the interim leader held two positions concurrently, they distributed some duties to other librarians or minimally performed some duties. At institutions where the previous library leader left for a job at another institution, 3.3 percent of respondents were able to backfill their regular position, while at institutions where the previous library leader retired, 19.2 percent of respondents were able to backfill their regular position. One respondent stated, "If there is a next time, I would delegate more where possible or hire a temporary staff member."

The number of participants who applied for the permanent position nearly equaled the number who did not. Of the 40 individuals (37.0\%) who applied for the permanent position, $32(80 \%)$ indicated they were hired for the permanent position. Of the remaining respondents, 45 people $(41.7 \%)$ did not apply and 23 people $(21.3 \%)$ marked "Other." Many of those who responded "Other" indicated that the search had not begun, and two indicated that the regular leader was on temporary leave. A number of participants discussed their experiences as a candidate for the permanent position. Those individuals hired for the permanent position commented that the interim period helped them to grow as leaders, gave others an opportunity to see their leadership style, and set them up for a smooth transition. One respondent observed that it was awkward to be an applicant and that she "had to enact and lead, but not overstate [her] acting role as an assumption for the permanent position." Another individual who was not hired stated, "The challenge is after serving as Interim; I am back in my prior role but not certain how I fit in here with the dean." Several people became leaders at other institutions as a result of the skills and experience they gained during their interim appointment.

Before accepting another interim position, many respondents would consider a range of factors. Nearly half of respondents (45.4\%) indicated they would be willing to serve as an interim leader in the future, and the same number of respondents selected "Maybe." A number of people stipulated that they would or might serve again depending upon many factors: the expectations and responsibilities of the appointment; the amount of compensation; the duration of the appointment; the point in their career or other personal circumstances; the institutional environment and culture; the level of support from library employees and institutional administrators; and whether or not they believed they could be successful in the role. Six of the participants who selected "Maybe" believed the compensation was insufficient compared to the volume of work and responsibilities. One respondent stated, "I would only do this with a finite contract ... and I would not do it simultaneously with my own position." Approximately 10 percent of participants were not willing to serve as an interim leader in the future because they planned to retire soon, they were not interested in administration, or they found it overwhelming to perform two jobs simultaneously.

\section{Interview Results}

From the 58 individuals who indicated a willingness to take part in a follow-up interview, the re- 
searchers selected 12 people whose characteristics paralleled the survey demographics. However, only 10 of the 12 individuals agreed to be interviewed, which resulted in a larger percentage of individuals from public institutions. (See table 1 for the personal demographics and institutional characteristics of the interviewees.) The participants candidly described their interim leadership experiences, and the researchers captured a deeper understanding of the participants' passion or angst. Of the 10 people interviewed, eight held department head or associate dean/associate university librarian positions at their institution before serving as the interim leader, and one had served previously as an interim. Four individuals had previous budgetary experience, and three had previous experience working with colleagues across the institution outside the library. While two people reported that they did not aspire to serve as the interim leader, both agreed to serve because they had more experience than other library managers. All interviewees stated that serving as an interim library leader was a positive experience. Two respondents were second-career librarians who had worked outside academia. While their management experience skills were helpful and transferable, both noted that "the academic world is different." One respondent who had prior leadership experience pointed out, "It's easy to say you can do the job, but it's on a different scale. As an associate dean or department head, you are a little naïve about the politics. You no longer have a person to look out for you."

\section{Discussion}

The goal of this research study was to build knowledge about interim library leadership and to guide future interim leaders and the university executives who appoint them. Three themes emerged from the open-ended survey question (Q15) and the interview transcripts: roles and expectations, learning and development, and relationships and support. A fourth theme emerged from the interview transcripts: advice for librarians considering an interim leadership position.

\section{Roles and Expectations}

Clarifying the roles and expectations of the interim position is essential. Sixty survey respondents commented on this topic. Several respondents recommended having a plan of action for the interim period, such as managing initiatives under way, filling library vacancies, improving communication within the library, improving the user experience with the library, preparing staff for the upcoming change in leadership, and moving the library forward. Several respondents advised interim leaders to "do what is best for the library" and to "stick to the mission of the institution." Some respondents described their interim role as a "caretaker," "seat-warmer," or "placeholder," while others were "encouraged to act as the dean" or served "without regard to the position being interim." A few respondents believed that their decisions and voice did not carry as much weight as that of a permanent leader. The majority of participants interviewed were advised to stick to the mission and goals of the library while calmly serving as the voice of reason during the transitional time. Four individuals were encouraged to act as if they were in charge and to accomplish as much as they could. One person, who worked at an institution with a collective bargaining unit, was told to read and memorize the contract.

\section{Learning and Development}

Study participants described what they learned in great detail. Forty-four survey respondents portrayed their interim period as a valuable learning experience and summed up the opportunity as great, enjoyable, valuable, fulfilling, rewarding, and energizing. However, 
several individuals described their experience as challenging, difficult, stressful, fear-filled, and demanding. Respondents mentioned specific skills they learned or expanded including advocacy, hiring, budgeting, prioritizing, solving problems, developing a tolerance for ambiguity, and articulating a vision. One respondent advised, "It's critical to know how to work effectively with people, to understand budgeting, to be politically savvy, and to possess strong communication skills in order to succeed." Another person observed, "The better you know your culture and the players, the greater your chances of success are." Survey participants reported learning to think big picture, learning more about operations across the library, gaining a broader perspective of the institution and its operations, being exposed to campus politics and dynamics, building alliances across the institution, and understanding the library's place in the hierarchy of the institution. While one respondent was surprised by how little she understood about library operations before her interim position, another respondent stated that he better understood the previous director's actions or inaction. Ten respondents appreciated that the interim opportunity enabled them to develop their leadership skills and build confidence in their abilities. One respondent declared that the interim role can be "a feather in your cap and a source of satisfaction." For several individuals, the interim experience helped them determine the direction of their career including whether they wanted to be a library leader. One respondent realized that, while the interim experience was not bad, the role of University Librarian was not the job for her. Another person stressed that "directorship may be for you or may not be for you, and there is no shame either way."

During the interview phase, the theme of learning continued in more depth. As a result of networking across campus, seven individuals understood how the library fit into the broader institutional context. Four participants enjoyed improving library operations by revising job descriptions, giving raises, or fostering collegiality and cooperation. Three individuals valued the opportunity to learn about fundraising, and others fine-tuned their time management skills or learned to delegate more effectively. Interview participants learned unexpected lessons as well. Half of the interviewees expressed surprise about the amount of information they could not share with library employees, and some admitted it was taxing to maintain confidentiality. One participant commented, "I thought I knew what my predecessor did, but now I see everything and what all happened behind the scenes." Some found it challenging to be transparent and open while withholding information about problems facing the institution (such as budget shortfalls or Title IX violations) until the university administration communicated this information. Two people mentioned the need to be flexible with their schedule when urgent issues would "pop up" and crowd out time allocated for important projects. Some interim leaders inherited unaddressed problems that created stress. One individual did not anticipate how much time it would take to address personnel issues and clean up "stuff" before the permanent leader arrived, while another observed that "moving a problem is not solving a problem." Another person felt isolated but believed that, just like royalty, leaders should "smile, wave, and never let them know how hard it is to bear."

\section{Relationships and Support}

Study participants spoke about the nature of relationships during their interim appointment. Of the 25 survey respondents who described relationships with library colleagues during and after the interim period, 17 recounted challenging situations while seven reported positive experiences. Negative comments included difficulties with "troublesome peers," colleagues 
who were "less than willing to see me succeed," or a "divided administrative team that often split along gender lines." Several people stated that library colleagues had difficulty accepting a former peer as a leader, especially when the length of service was not a criterion for appointing the interim leader. One respondent commented that "even four years later, I still feel like a bit of an outsider to my peers." The seven individuals who positively described their relationships indicated that the library faculty and staff were supportive, accepting, cooperative, eager, and flexible. One respondent commented that the interim leader needs "to have the goodwill of your team to be successful" and another added that "people need reassurance and guidance ... they need to trust you." Finally, one respondent stated that the library employees were "very talented people and the best thing for the library was to let them do their jobs to the best of their ability, supporting and guiding them when needed."

Participants also described the range of support they received. Eighteen survey respondents appreciated having support from the provost, individuals in Human Resources and Labor Relations, library faculty and staff, the previous library dean or director, and other library leaders in the region. During the interviews, six people reported receiving significant support and guidance from their provost and other deans in their institution. Four individuals described assistance received from library department heads, while six sought advice from the former library dean or library deans at other institutions. Despite multiple sources of help, the interim leader often "just has to wing it and do the job." As noted in the survey results, some interim leaders experienced extended appointments due to unforeseen circumstances. One participant considered the extension to be good news, stating that "less guidance is needed because the job gets easier the longer you have it."

\section{Advice for Future Interim Leaders}

Overwhelmingly, interviewees advised librarians considering an interim leadership role to ask questions about expectations and to grow one's networks both on campus and in the library community. Whether one accepts an interim position eagerly or reluctantly, one's experiences will vary based on personal, professional, and institutional circumstances. The interviewees advised librarians who intended to return to their previous position at the conclusion of the interim period to "play nicely." Finally, the participants observed that interim leaders could put their "stamp on the library," "leave a legacy," and "sprinkle seeds that grease the skids for the future."

In retrospect, interviewees wished they could have known how much time and effort it would take to perform the interim job. Half of those interviewed reflected on work-life balance and self-care. One individual observed that they could "never dial it off" and felt the need to check emails all hours of the day to address urgent matters. Another person commented that the role "is more political than you ever thought." The majority of interviewees were asked to serve in the role longer than was anticipated, and they reflected about the impact that had on their personal lives. Many individuals wished they had asked for more help from university administration, that they had backfilled their former position, and that they had negotiated a higher salary.

\section{Significance of the Study}

This research study is important for several reasons. Previous articles about interim leadership were qualitative and focused on one person or several individuals. This mixed-methods study builds on existing literature and fills a gap by exploring the experiences of 108 interim library leaders. The findings synthesize the collective wisdom of librarians who have served 
as interim leaders. While academic institutions frequently appoint interim leaders, librarians may only serve in this role once during their career. Future interim library leaders will be better able to make an informed decision about serving in this role and may be more effective during the interim period. Provosts and other academic administrators who appoint interim library leaders will have a better understanding of the concerns and needs of temporary leaders. The results are useful and transferable.

\section{Recommendations for Practice}

Several similarities existed for the majority of respondents. Two interesting survey responses emerged: 79.5 percent of survey participants held their regular position concurrently with their interim position, and more than 90 percent of respondents were willing or might be willing to serve again as an interim leader. Numerous individuals described positive learning experiences, developed a broader and deeper understanding of the library and its parent institution, learned or honed skills, established relationships with colleagues across the institution, and noted the importance of having a support network. Given the high proportion of responses in these areas, future interim library leaders are likely to have similar experiences.

While the participants' experiences revealed some similarities, each interim leader's situation was unique and distinctive. Variables included the circumstances surrounding the departure of the incumbent library leader, the duration of the appointment, expectations and responsibilities, the level of support from university administrators and library colleagues, the skills and knowledge possessed by the interim leader, and the institution's culture and initiatives. Interim library leaders might not know these factors in advance and cannot predict what might occur during the vacancy period. The interim leader's charge strongly influenced the experience and knowledge they gained: maintain the status quo and learn a modest amount, or advance the library's agenda and learn a great deal. Focusing on one's charge is the most important duty of an interim leader.

Future interim leaders can draw on the experiences of these study participants. When accepting a temporary appointment, clarify expectations and establish an action plan. Regardless of the time period specified, plan to serve longer than requested. Build your professional network both on campus and at the state and national levels. Ask for support from university and professional colleagues. Accept that relationships with coworkers will change. Practice good self-care. Carefully consider whether to apply for the permanent position. Reflect on how the experience will impact the future of your career.

Interim leaders inevitably will have gaps in their knowledge and should establish a professional development plan. For example, one may develop advocacy and fundraising skills by attending workshops locally or nationally. One may increase political skill through conversations with an executive coach or a trusted mentor. Attending campuswide leadership meetings and one-on-one meetings with campus administrators will broaden one's knowledge of local operations. Instead of only attending library-related conferences, attend national conferences sponsored by higher education associations.

Based on the results of this study, the researchers recommend that provosts set clear and realistic expectations for the interim period, support interim leaders as they navigate university operations and politics, and arrange intentional learning opportunities. According to study participants, the interim period should be brief, and compensation should be commensurate with the interim responsibilities and other similar positions on campus. The longer the duration of 
the interim period, the more necessary it will be to backfill the interim leader's regular position.

\section{Limitations and Future Research}

This study focused on librarians who served in interim leadership roles at U.S. academic institutions between 2012 and 2017. Because no official list of interim library leaders exists and the respondents self-identified, the sample was one of convenience. The authors could not determine whether the respondents were representative, and the results cannot be generalized. Researchers could investigate interim leader experiences at institutions within a specific Carnegie level or could examine whether age or race impacts the selection of interim leaders or their experiences during the interim period. Due to the title of the survey, individuals whose job title was Interim Director rather than Interim Dean or Interim University Librarian may not have participated in this study. The titles of future surveys could be more inclusive to encourage broader participation. Also, researchers could identify potential participants using the snowballing technique or could distribute the survey link more widely through discussion lists hosted by state associations or local ACRL chapters.

Some survey results were puzzling. The authors did not determine why 32.4 percent of respondents had fewer than five years of previous leadership experience or why 24.3 percent of respondents had worked at their institution for less than five years. (See figure 1.) There appeared to be a tendency to appoint librarians with less leadership experience and fewer years of service at the institution. Future studies could explore this finding to confirm or disprove it. Also, out of 40 individuals who applied for the permanent position, 32 (80\%) indicated they were hired for the permanent position. The percentage of internal candidates hired seemed high and may be an anomaly of this study's participants. Further analysis revealed that 7 of those who were hired worked at doctoral institutions, while 22 of those who were hired worked at master's-degree institutions. Future studies could examine whether a relationship exists between hiring an internal candidate and the level of degree-granting or the size of an institution.

Additionally, future research could explore questions unanswered by this study. Topics might include how academic libraries plan for leadership transitions, how library leaders develop political skills, and what barriers prevent mobility upward in levels of academic library leadership. Finally, researchers could study provosts' expectations of and experiences supervising interim leaders.

\section{Conclusion}

Being asked to serve as an interim leader may come as a surprise or may be anticipated. Librarians appointed to an interim role may shift from being an expert in their practice to being a neophyte in campus operations. An interim leader's attention may cycle quickly between internal details and external matters. These changes may be disorienting. Listen to your gut. Learn as much as you can from whomever you can. Care about the institution's mission. Appreciate the people with whom you work. Dream big and accomplish what you can while you serve in the interim role.

Accepting an interim leadership position is an act of courage. Obtaining top-level leadership experience may be the essential ingredient needed to advance one's career. On the contrary, one may find the politics and responsibility to be greater than anticipated or desired. In either case, serving as an interim library leader can be a once-in-a-lifetime opportunity well worth the experience. 


\section{APPENDIX A. Survey Instrument}

\section{Experiences of Academic Librarians Serving as Interim Deans/University Librarians}

Thank you for your interest in this survey. This research project seeks to explore the experiences of individuals who currently serve or have served in interim roles at the topmost level in academic libraries in the United States between 2012 and the present. Titles for these roles might include Interim Dean or Interim University Librarian. The survey is not intended for individuals who may be serving in interim roles at the assistant or associate level or in middle management. The survey will take approximately 15 minutes to complete, and participation is voluntary. Data will be stored for the duration of the research project, and aggregate data selected comments may be published.

1. By continuing with this survey, I am indicating my consent to participate in this research.
a. Agree
b. Disagree $\rightarrow$ SKIP TO NOT ELIGIBLE

2. My title as an interim library leader is/was: SELECT ONE
a. Interim Dean $\rightarrow$ SKIP TO QUESTION 4
b. Acting Dean $\rightarrow$ SKIP TO QUESTION 4
c. Interim University Librarian $\rightarrow$ SKIP TO QUESTION 4
d. Acting University Librarian $\rightarrow$ SKIP TO QUESTION 4
e. Interim Director $\rightarrow$ SKIP TO QUESTION 3
f. Acting Director-SKIP TO QUESTION 3
g. Interim or Acting Department Head $\rightarrow$ SKIP TO NOT ELIGIBLE
h. Interim or Acting Branch Librarian $\rightarrow$ SKIP TO NOT ELIGIBLE
i. $\quad$ Other $\rightarrow$ SKIP TO NOT ELIGIBLE

3. If your title is/was Interim or Acting Director, is/was that position the topmost library leader position at your institution?
a. Yes $\rightarrow$ SKIP TO QUESTION 4
b. No $\rightarrow$ SKIP TO NOT ELIGIBLE

4. I am serving or have served as Interim Dean or University Librarian during the following year(s): SELECT ALL THAT APPLY
a. 2012
b. 2013
c. 2014
d. 2015
e. 2016
f. 2017
g. Other-please specify

5. What event(s) led to your serving in the interim position? SELECT ALL THAT APPLY

a. Previous Dean/University Librarian retired

b. Previous Dean/University Librarian was promoted to a position elsewhere in the same institution 

c. Previous Dean/University Librarian left for a job at another institution
d. Other-please specify

6. For what period of time were you asked to serve in the interim position? SELECT ONE
a. Less than 3 months
b. 4-6 months
c. $7-12$ months
d. $12-18$ months
e. $18-24$ months
f. More than 24 months
g. Other-please specify

7. How long did you serve in the interim position? SELECT ONE
a. Less than 3 months
b. $4-6$ months
c. $7-12$ months
d. 12-18 months
e. 18-24 months
f. More than 24 months
g. Other-please specify

8. If the interim period ended up being shorter or longer than originally anticipated, why was that?

9. What do you believe is the ideal length of time to serve in an interim position?
a. Less than 3 months
b. 4-6 months
c. $7-12$ months
d. $12-18$ months
e. $18-24$ months
f. More than 24 months
g. Other-please specify

10. What happened to your regular position during the interim period? SELECT ONE
a. My regular position was backfilled
b. My regular position was not backfilled
c. I held both my regular position and the interim position simultaneously
d. Other-please specify

11. As an interim, my duties included: SELECT ALL THAT APPLY
a. All of the regular duties of the Dean/University Librarian position
b. Some but not all of the regular duties of the Dean/University Librarian position
c. All of the duties of my regular position
d. Some of the duties of my regular position
e. Other-please specify 
12. Did you apply for the permanent position?
a. Yes
b. No
c. Other-please specify

13. Were you hired for the permanent position?
a. Yes
b. No
c. Search for new Dean/University Librarian is under way
d. Search for new Dean/University Librarian has not begun
e. Other-please specify

14. If you were to be asked to serve as an interim leader in the future, would you agree to do so?
a. Yes
b. No
c. Maybe
d. Other-please specify

15. In three sentences or less, what would you most like to share about your experience serving as Interim Dean/University Librarian?

16. I work at an institution located in the United States.
a. Yes
b. No

17. Gender
a. Male
b. Female
c. Prefer not to answer
d. Not listed (please specify)

18. Years of service at same institution prior to serving as Interim Dean/University Librarian
a. $0-5$ years
b. $6-10$ years
c. $11-15$ years
d. 16-20 years
e. 21-25 years
f. More than 25 years

19. Years of service as a librarian prior to serving as Interim Dean/University Librarian
a. $0-5$ years
b. $6-10$ years
c. $11-15$ years
d. 16-20 years
e. 21-25 years
f. More than 25 years 
20. Total years of service as a leader (at any level) prior to serving as Interim Dean/University Librarian
a. $0-5$ years
b. 6-10 years
c. $11-15$ years
d. 16-20 years
e. 21-25 years
f. More than 25 years

21. Type of institution:
a. Public
b. Private

22. Degrees conferred (as defined by Carnegie Classifications, http://carnegieclassifications. iu.edu/classification_descriptions/basic.php)
a. Doctorate (R1, R2, R3)
b. Master's (M1, M2, M3)
c. Baccalaureate College
d. Associate's College
e. Other (please specify)

23. Number of students:
a. Fewer than 5,000
b. $5,001-10,000$
c. $10,001-20,000$
d. 20,001-30,000
e. More than 30,000

24. Number of regular library employees (faculty and staff, not student employees)
a. 1-10
b. $11-25$
c. 26-50
d. 51-100
e. $101-200$
f. More than 200

25. Size of library budget:
a. Less than $\$ 1$ million
b. \$1-\$4.9 million
c. \$5-\$9.9 million
d. \$10-\$19.9 million
e. \$20-\$49.9 million
f. \$50-\$99.9 million
g. More than $\$ 100$ million 
26. Are you willing to participate in an interview about your experiences serving as Interim Dean/University Librarian?

a. No $\rightarrow$ Skip to thank you

b. Yes

27. Thank you for agreeing to participate in a telephone interview. An investigator will contact you to schedule an appointment. It is expected that the interview will take 30 minutes. Please provide your contact information below:

a. First and Last Name

b. Telephone Number

c. Email Address

Thank you for taking time to participate in our survey. We value the information you have provided. Your responses will be used to build a broader understanding of interim academic library leadership. 


\section{APPENDIX B. Structured Interview Protocol}

\section{Experiences of Academic Librarians Serving as Interim Dean/University Librarian}

This interview is an optional follow-up to the survey you completed about the experiences of individuals who currently serve or have served in interim roles at the topmost level in academic libraries in the United States between 2012 and the present. Thank you for agreeing to be interviewed!

This interview will take approximately 30 minutes to complete, and participation is voluntary. Data will be stored for the duration of the research project, and selected quotes may be published. Any information you share that is published will not include identifying information. Participation in this interview implies consent. Do you have any questions before we begin?

1. What past experiences in your professional life prepared you for the interim position?

2. What support or guidance did you receive during the interim period and from whom? (Prompt if needed: Provost, within the library, other administrators, other deans, library leaders from other institutions)

3. What was the best advice you received? (Prompt if needed: from whom?)

4. What were the positive aspects of your experience?

5. What aspects of the job did you not anticipate or foresee? (Prompt if needed: What struggles did you face?)

6. What do you wish you would have known or asked about before agreeing to serve as interim?

7. What might you do differently if you could do it over?

8. What advice or suggestions would you offer to someone who may be considering an interim position?

9. Is there anything else you would like to share about your experience as an interim leader?

Thank you for agreeing to participate in this interview and for sharing your experiences with us! We value the information you have provided. Your responses will be used to build a broader understanding of interim academic library leadership. We look forward to writing about our findings and would be happy to notify you when the study is published.

10. May we contact you if we have follow-up questions?
a. Yes
b. No

11. Would you like to be notified of publication of results?
a. Yes
b. No

12. If respondent answers yes to questions 10 or 11 above, record contact information below.

a. First and Last Name

b. Email Address

c. Telephone Number

\section{Notes}

1. Cynthia L. Fountaine, "Stepping In: The Unique Challenges Faced by Interim Law Deans," University of Toledo Law Review 40, no. 2 (2009): 345; Mary H. Mundt, "Leading in a Time of Change: Assuming Interim 
Academic Administrator Positions," Journal of Nursing Education 43, no.11 (2004): 496.

2. Maggie M. Farrell, "Interim Leadership," Journal of Library Administration 56, no. 8 (2016): 991, doi:10.1080 /01930826.2016.1231547; Fountaine, "Stepping In," 345; Mundt, "Leading in a Time of Change," 496.

3. Fountaine, "Stepping In," 343; Mundt, "Leading in a Time of Change," 496.

4. Farrell, "Interim Leadership," 991.

5. Diane Klare, "The Accidental Director: Critical Skills in Academic Library Leadership. Library Leadership $\mathcal{E}$ Management 31, no. 2 (2017): 2.

6. Fountaine, "Stepping In," 343.

7. Norm Medeiros, "Training Ground: The Role of Interim Library Director," OCLC Systems E Services: International Digital Library Perspectives 26, no. 3 (2010): 153, doi:10.1108/10650751011073580.

8. Farrell, “Interim Leadership," 996; Medeiros, “Training Ground," 155.

9. Farrell, "Interim Leadership," 993, 997; Mark Stover, "From Reference Librarian to Interim Dean: A Journey of Comparisons and Contrasts," Reference E User Services Quarterly 50, no. 4 (2011): 324.

10. Farrell, "Interim Leadership," 993; Mundt, "Leading in a Time of Change," 499-500.

11. Cynthia J. Boyle et al., "The Influence of Interim Deans: More than Keeping the Ship Afloat and Warming the Captain's Seat," American Journal of Pharmaceutical Education 80, no. 7 (2016): article 112, 3, available online at www.ajpe.org/doi/abs/10.5688/ajpe807112 [accessed 17 June 2017].

12. Boyle et al., "The Influence of Interim Deans," 1; Farrell, "Interim Leadership," 992-93; Fountaine, "Stepping In," 345.

13. David J. Bachrach, "Up for an Interim Promotion? Learn How to Overcome the 'Curse' of Being the Internal Candidate," Academic Physician \& Scientist (Mar./Apr. 2001): 8, available online at https://www.aamc. org/download/266440/data/aps2001-03bachrachinterimpromotion.pdf [accessed 17 June 2017]; Farrell, "Interim Leadership," 994; Mundt, "Leading in a Time of Change," 499.

14. Mundt, "Leading in a Time of Change," 499.

15. Boyle et al., "The Influence of Interim Deans," 4; Farrell, “Interim Leadership," 991.

16. Douglas T. Hall, "Unplanned Executive Transitions and the Dance of the Dubidentities," Human Resource Management 34, no. 1 (1995): 77, 80; Eric C. Shoaf, "Suddenly Directing! An Interview with Florence Doksansky," Library Administration \& Management 19, no. 3 (2005): 116.

17. Bachrach, “Up for an Interim Promotion?" 8; Gail Munde, “My Year as Interim: Six Things I Learned for Free," College E Research Libraries News 61, no. 5 (2000): 417.

18. Munde, "My Year as Interim," 417; Shoaf, "Suddenly Directing!" 117.

19. Farrell, "Interim Leadership," 994; Munde, "My Year as Interim," 416.

20. Medeiros, "Training Ground," 154; Pat A. Newcome et al., "Becoming Director: An Internal Candidate's View," Library Management 34, no. 3 (2013): 189, doi:10.1108/01435121311310888.

21. Quinn Galbraith et al., "A Case for Succession Planning: How Academic Libraries Are Responding to the Need to Prepare Future Leaders," Library Management 33, no. 4/5, (2012): 232, doi:10.1108/01435121211242272.

22. Ibid.

23. Fountaine, "Stepping In," 349-51; Munde, "My Year as Interim," 416-17; Shoaf, "Suddenly Directing!" 324.

24. Farrell, "Interim Leadership," 996.

25. Munde, "My Year as Interim," 416; Shoaf, "Suddenly Directing!" 118.

26. Farrell, "Interim Leadership," 999; Munde, "My Year as Interim," 416; Shoaf, "Suddenly Directing!" 118.

27. Munde, "My Year as Interim," 417.

28. Kevin Deemer, "A View from Above, Looking Back, Moving Forward: A Librarian's Experience Working as an Interim Assistant Dean," College E Research Libraries News 68, no. 1 (2007): 26, doi:10.5860/crln.68.1.7735.

29. Fountaine, "Stepping In," 347.

30. Munde, "My Year as Interim," 417.

31. Farrell, "Interim Leadership," 997-98.

32. Klare, "The Accidental Director," 3.

33. Fountaine, "Stepping In," 345-46.

34. Farrell, "Interim Leadership," 997; Rochelle Logan, "Executive Transitions: My Time as an Interim Director," Public Libraries 53, no. 6 (2014): 19.

35. Hall, “Unplanned Executive Transitions," 76.

36. Hall, "Unplanned Executive Transitions," 85-86.

37. Klare, "The Accidental Director," 6.

38. Munde, "My Year as Interim," 417.

39. Shoaf, "Suddenly Directing!" 117-18. 
40. Boyle et al., "The Influence of Interim Deans," 2; Medeiros, "Training Ground," 155.

41. Boyle et al., "The Influence of Interim Deans," 4; Farrell, "Interim Leadership," 998; Logan, "Executive Transitions," 19.

42. Farrell, "Interim Leadership," 998; Shoaf, "Suddenly Directing!" 118.

43. Boyle et al., "The Influence of Interim Deans," 2.

44. Mundt, "Leading in a Time of Change," 501.

45. U.S. Census Bureau, "Full-Time, Year-Round Workers and Median Earnings in the Past 12 Months by Sex and Detailed Occupation: 2015," available online at https://www.census.gov/data/tables/time-series/demo/ industry-occupation/median-earnings.html [accessed 17 June 2017].

46. Center for Postsecondary Research, "2015 Carnegie Classifications Update: The Carnegie Classification of Institutions of Higher Education," available online at http://carnegieclassifications.iu.edu/downloads/CCIHE2015FactsFigures.pdf [accessed 17 June 2017].

47. Ibid. 